\title{
Ostatni niewolni we współczesnej Europie - relikty poddaństwa na Spiszu i ich zniesienie w latach trzydziestych XX w.
}

Słowa kluczowe: Spisz, II Rzeczpospolita, pańszczyzna, ustawa z 20 III 1931 r.

Keywords: Spiš, Second Polish Republic, serfdom, act of Polish Parliament of 20 March 1931

\begin{abstract}
In Polish Spiš, incorporated on 28 July 1920 into the Second Polish Republic, there were three villages (Niedzica, Falsztyn and Niżne Łapsze) which belonged to two related families (the Salamons and the Jungenfelds). These villages were relics of feudalism in the form of serfdom of one of the categories of local peasants referred to as "żelarze". This problem, solved in two stages in Hungary in 1848 and 1896, in Polish Spiš was not eliminated until 20 March 1931 when a legal act led to enfranchisement of "żelarze" by way of purchase over the next three years.
\end{abstract}

Powszechnie sądzi się, że koniec poddaństwa ludności chłopskiej w Europie Środkowej nastąpił w połowie XIX w. Na ziemiach polskich przyjmuje się lata 1811-1864'. Najpierw dokonało się to na ziemiach zaboru pruskiego, gdzie w latach 1811-1850

1 Na temat całokształtu procesu uwłaszczenia na ziemiach polskich zob. zwł. dwie starsze, ale wciąż aktualne prace: K. Groniowski, Uwłaszczenie chłopów w Polsce, Warszawa 1976; T. Mencel, Wieś pańszczyźniana w Królestwie Polskim w połowie XIX wieku, Lublin 1988. 
na mocy edyktów zniesiono pańszczyznę kolejnych kategorii ludności chłopskiej² Następnie doszło do częściowego jej ograniczenia na terenie Królestwa Polskiego, na mocy ukazu cara Mikołaja I, co zostało później rozszerzone przez cara Aleksandra II na kolejne przypadki w 1861 r. ${ }^{3}$ Całkowity koniec pańszczyzny w Królestwie Polskim nastąpił dwa lata później, kiedy to ukazem podpisanym 2 III 1864 r. Aleksander II zniósł okup pańszczyźniany i czynsz dzierżawny na rzecz właściciela gruntu w zamian za podatek gruntowy na rzecz skarbu carskiego ${ }^{4}$. Wcześniej, bo w 1848 r., pańszczyzna została zniesiona na terenie zaboru austriackiego ${ }^{5}$. Wydawać by się mogło zatem, że w momencie odzyskania niepodległości po pierwszej wojnie światowej i podczas budowy odrodzonego państwa polskiego ten przeżytek epoki feudalnej nie istniał na polskich ziemiach. Prawda okazuje się zgoła inna, bowiem do początku lat trzydziestych XX w. w granicach II Rzeczypospolitej znajdował się obszar, na którym istniały stosunki pańszczyźniane.

Regionem tym był fragment Spiszu, który po dwuletnich sporach pomiędzy Polską i Czechosłowacją został w końcu włączony do Polski decyzją Rady Ambasadorów z 28 VII 1920 r. $^{6}$ Ten położony w górach obszar, słabo skomunikowany z sąsiednimi terenami, obejmował powierzchnię $195,5 \mathrm{~km}^{2}$, na których było zlokalizowane 13 wsi z 8747 mieszkańcami. Relikty pańszczyzny przetrwały w trzech z nich, a mianowicie w Niedzicy, Falsztynie oraz Łapszach Niżnych. Wioski te należały do węgierskiego rodu hrabiów Salamonów oraz spokrewnionego z nim zmadziaryzowa-

2 A. Mączak, Encyklopedia historii gospodarczej Polski do 1945 roku, Warszawa 1981, t. 2, s. 34; Historia państwa i prawa Polski, red. J. Bardach, t. III, Warszawa 1981, s. 593 n.; W. Rusiński, Zarys Historii Gospodarczej Polski na tle dziejów gospodarczych powszechnych, Warszawa 1986, s. 104 n.; C. Łuczak, Dzieje gospodarcze Wielkopolski w okresie zaborów 1815-1918, Poznań 2001.

3 J. Rutkowski, Historia gospodarcza Polski do 1864 r., Warszawa 1953, s. 311; Historia państwa i prawa Polski, t. III, s. 261 n.

4 A. Mączak, Encyklopedia historii gospodarczej, t. 2, s. 447 n.; Historia państwa i prawa Polski, t. IV, Warszawa 1982, s. 98 n. oraz zwł. J. Szumski, Uwłaszczenie chłopów w północno-wschodniej części Królestwa Polskiego 1846-1871, Białystok 2002, s. 117 n., gdzie bardziej szczegółowe przedstawienie zagadnienia.

5 J. Rutkowski, Historia gospodarcza Polski, s. 318; Historia państwa i prawa Polski, t. III, s. 694 n.; Historia państwa i prawa Polski, t. IV, s. 326 i nast.; K. Ślusarek, Kwestia agrarna w Galicji w latach 1848-1861, [w:] Galicja i jej dziedzictwo, t. 12: Galicja w 1848 roku. Demografia, działalność polityczna i społeczna, gospodarka i kultura, red. A. Bonusiak, M. Stolarczyk, Rzeszów 1999 oraz tenże, Uwłaszczenie chłopów w Galicji zachodniej, Kraków 2002.

6 E. Orlof, Orawa i Spisz w latach 1918-1920, [w:] Spisz i Orawa. W 75. rocznice powrotu do Polski pótnocnych części obu ziem, red. T.M. Trajdos, Kraków 1995, s. 23 n. 
nego niemieckiego rodu baronów Jungenfeld, którzy Falsztyn i cześć Łapsz Niżnych otrzymali na skutek małżeństwa z Salamonami ${ }^{7}$. Istnienie w tym rejonie pozostałości ustroju feudalnego spowodowane było tym, że obowiązywało tu prawo węgierskie, jako że Spisz wchodził w skład Królestwa Węgier zachowującego pewne odrębności, $\mathrm{w}$ tym prawne, w ramach monarchii austro-węgierskiej. Z kolei wraz z odzyskaniem niepodległości w $1918 \mathrm{r}$. Rzeczpospolita Polska nie uchyliła praw obowiązujących na poszczególnych jej obszarach wcześniej, zachowując co do zasady, do czasu uchwalenia nowych ustaw, prawa obowiązujące dotychczas. Przykładowo, w zakresie prawa cywilnego przez cały okres II Rzeczypospolitej obowiązywały trzy kodeksy: rosyjski, pruski i austriacki oraz częściowo regulacje węgierskie na obszarze Spiszu i Orawy.

Pańszczyzna została co prawda zniesiona w połowie XIX w. również na Węgrzech, jednak nie dotyczyła ona wszystkich przypadków na terenie królestwa. Ustawy uwłaszczeniowe (ustawa nr IX i XI) uchwalone przez węgierski sejm stanowy 18 III 1848 r. zniosły bowiem jedynie pańszczyznę wynikającą z umowy urbarialnej, pomijając zupełnie chłopów pańszczyźnianych, których powinności wobec panów feudalnych wynikały ze stosunków alodialnych i umownych, oraz służbę folwarczną ${ }^{9}$ Problem więc rozwiązano jedynie częściowo, pozostawiając blisko dwie trzecie ludności wiejskiej dotkniętej obowiązkiem pańszczyzny poza regulacjami tych ustaw $^{10}$. Było to oczywiście w interesie szlachty węgierskiej, której zyski nadal oparte były głównie na taniej sile roboczej poddańczej ludności mieszkającej w ich dobrach $^{11}$. Ta sama przyczyna leżała u podstaw późniejszych postaw rodów Salamonów i Jungenfeldów, niechcących rezygnować z trwającej od stuleci renty odrobkowej, do której obowiązana była część chłopów mieszkających w ich dobrach.

Zagadnieniem specyficznych stosunków pańszczyźnianych na obszarze polskiego Spiszu w okresie dwudziestolecia międzywojennego zajęło się dotąd dwoje badaczy. Pierwsza była Maria Hulewiczowa, która w opublikowanym w 1938 r. artykule przedstawiała wyniki swoich wcześniejszych badań etnograficznych poświęconych

7 M. Hulewiczowa, Pozostałości ustroju pańszczyźnianego w XX wieku na polskim Spiszu i Orawie, Roczniki Dziejów Społecznych i Gospodarczych 7 (1938), s. 110.

8 E. Borkowska-Bagieńska, Historia prawa sądowego, Warszawa 2006, s. 103; por. też F.X. Fierich, Unifikacja ustawodawstwa, [w: ] Dziesięciolecie Polski odrodzonej. Księga pamiątkowa 1918-1928, Kraków-Warszawa 1928, s. 263.

9 M. Laclaviková, Dejiny štáitu a práva na územi Slovenska (1848-1948), Krakov 2014, s. 23.

10 J. Ciągwa, Zniesienie pańszczyzny na Spiszu w latach 1931-1934, Studia Iuridica Lublinensia 25 (2016), z. 3, s. 166, przyp. 1.

11 W. Felczak, Historia Wegier, Wrocław 1983, s. 228. 
ukazaniu specyfiki życia ostatnich spiskich „żelarzy” ${ }^{12}$. Drugim autorem był Józef Ciągwa, który ukazał przebieg procesu uwłaszczeniowego na przełomie lat dwudziestych i trzydziestych $\mathrm{XX} \mathrm{w.}{ }^{13}$ Poza tymi publikacjami posiadamy na ten temat jedynie krótkie wzmianki w opracowaniach syntetycznych, głównie dotyczących historii Spiszu czy historii prawa polskiego, oraz kilka opracowań popularyzatorskich o charakterze publicystycznym ${ }^{14}$. Lepiej przedstawia się natomiast podstawa źródłowa umożliwiająca poznanie tego zagadnienia. W pierwszej kolejności należy wymienić tu akta normatywne węgierskie i polskie, w tym ustawy znoszące stosunki żelarskie w Królestwie Węgier ${ }^{15}$ i II Rzeczypospolitej ${ }^{16}$. Interesującym świadectwem jest ponadto krótki pamiętnik „ostatniego żelarza” Jana Janosa powstały w 1959 r., a opublikowany dwa lata później ${ }^{17}$. Najwięcej do poniższych badań wniosły jednak źródła archiwalne, powstałe głównie w toku prac nad uwłaszczeniem polskich żelarzy pod koniec lat dwudziestych i w pierwszej polowie lat trzydziestych XX w. ${ }^{18}$

Terminy „żelarze” i „żelarstwo” wywodzą się z języka węgierskiego, gdzie w ten sposób określano rodzaj ludności chłopskiej i stosunku feudalnego łączącego chłopa z panem gruntowym. Określenia te pochodziły od rzeczownika „zsellér”, w języku węgierskim oznaczającego bezrolnego chłopa osiadłego w dobrach pana, który w zamian za prawo wzniesienia chałupy na pańskim gruncie, dzierżawienia małego poletka pańskiej roli ${ }^{19}$ oraz prawa do drewna na budowę i opał z pańskiego lasu był zobowiązany do pracy pańszczyźnianej bez sprzężaju w dobrach pana gruntowego. Od terminu „zsellér” powstał węgierski termin „zsellérség” określający tę instytucję stosunku chłopa do pana gruntowego, który przeszedł do języka słowackiego, przy-

12 M. Hulewiczowa, Pozostałości ustroju pańszczyźnianego, s. 107-139.

13 J. Ciągwa, Zniesienie pańszczyzny, s. 165-178.

14 Przykładowo krótkie omówienie E. Łukuś, Jan Janos - ostatni żyjący żelorz, Na Spiszu 60 (2006) nr 3, s. 9; czy artykuł z 2018 r. M. Zoń, Jak odrabiano pańszczyznę w II RP, Kurier Historyczny, https://kurierhistoryczny.pl/artykul/jak-odrabiano-panszczyzne-w-ii-rp,432 [dostęp: 3 [ 2021].

15 Ustawa węgierska nr IX/1848; Ustawa węgierska nr XI/1848; Ustawa węgierska nr XXV/ 1896.

16 Ustawa z dnia 20 marca 1931 r. o likwidacji stosunków żelarskich na Spiszu, Dz.U. Nr 37 z 1931 r., poz. 288.

17 W. Jostowa, Pamiętnik żelarza Jana Janosa, Wierchy 30 (1961), s. 192-196.

18 Źródła te znajdują się w Archiwum Narodowym w Krakowie oraz Archiwum Akt Nowych w Warszawie.

19 Wedle źródeł węgierskich było to 2-3 tzw. jutra (utra) ziemi, co odpowiadało obszarowi od ok. 86 do 130 arów. 
bierając odpowiednio formy „želiar” i „želiarka”20, a następnie zaistniał w spolszczonej formie jako „żelarz” i „żelarstwo”.

Wśród żelarzy na Węgrzech do połowy XIX w. istniało rozróżnienie na dwie grupy: żelarzy urbarialnych oraz żelarzy alodialnych zwanych później umownymi. Rozróżnienie to wynikało z podstawy prawnej ich położenia. Pierwsi, stanowiący historycznie starszą grupę, wywodzili się z ludności pańszczyźnianej, której położenie wynikało z mocy prawa - systemu feudalnego średniowiecznego królestwa węgierskiego. Liczba żelarzy urbarialnych, w średniowieczu stosunkowo niewielka, zaczęła gwałtownie rosnąć w XVIII w., tak że w kolejnym stuleciu stał się to istotny problem społeczny. W efekcie w 1848 r. mocą dwóch ustaw węgierskich, żelarze urbarialni zostali uwłaszczeni w ten sposób, że panowie feudalni dostali odszkodowanie od państwa za każdego żelarza, a ziemię, którą dotąd dzierżawili, żelarze musieli wykupić od właścicieli ${ }^{21}$. W zamian odtąd nie musieli pracować na polach panów feudalnych, a ich domy i zabudowania gospodarcze przeszły na ich własność. W praktyce większość żelarzy nadal pracowała na dworze pana, z tym że już jako robotnicy rolni najemni.

Druga z grup żelarzy, a więc żelarze alodialni, wykształciła się później, w okresie nowożytnym. Podstawą prawną sytuacji tej grupy nie było prawo feudalne, lecz umowa zawarta pomiędzy danym chłopem a panem gruntowym. Umowy te często nie były spisywane, a opierały się jedynie na umowie ustnej, z tej przyczyny, że większość tej ludności, stanowiącej najbiedniejszą część ludności chłopskiej na Węgrzech i Słowacji, była analfabetami. W efekcie sytuacja tej grupy była najczęściej dużo gorsza niż żelarzy urbarialnych, co przejawiało się znacznie większym wymiarem dni pracy na ziemi pana. Grupa ta została całkowicie pominięta w ustawach z $1848 \mathrm{r}$. i dopiero ustawa z 1896 r. umożliwiła im likwidację stosunków pańszczyźnianych na zasadzie umowy z panem gruntowym oraz wykupu ziemi i zabudowań dzierżawionych przez samych żelarzy ${ }^{22}$.

20 Na temat terminologii w języku węgierskim oraz słowackim zob. Magyar jogi lexikon, t. 6, Budapest 1907, s. 550 oraz Slovnik slovenského jazyka, t. 5, Bratislava 1965, s. 795 n. Por. też hasło želiari [w:] Encyklopedia Slovenska, t. 6, Bratislava 1982, s. 637.

21 Ustawy węgierskie nr IX/1948 oraz XI/1948. Por. J. Mésároš, K problematiké prežitkov feudalizmu na Slovensku v druhej polovici 19. storočia, Bratislava 1955, s. 32; W. Felczak, Historia Węgier, s 226 n.; J. Ciągwa, Zniesienie pańszczyzny, s. 168; P. Mosnsý, L. Hubenák, Dejiny štátu a práva na Slovensku, Košice 2008, s. 83; P. Mosnsý, M. Laclavíková, Dejiny štátu a práva na území Slovenska, t. 2: 1848-1948, Bratislava 2020, s. 23.

22 Ustawa węgierska nr XXV/1896. Por. J. Mésároš, K problematiké prežitkov feudalizmu, s. 39; J. Beňa, T. Gábriš, Dejiny práva na Slovensku I (do roku 1918), Bratislava 2015, s. 239. 
Termin ten był powszechnie używany również na Słowacji, w tym na Spiszu. Znany był również w Polsce po 1918 r., o czym świadczy stosowanie go w dokumentach, ówczesnych opracowaniach ${ }^{23}$ oraz w samej Ustawie z dnia 20 marca $1931 \mathrm{r}$. o likwidacji stosunków żelarskich na Spiszu (Dz. U. nr 37, poz. 288). W artykule 1 cytowanej ustawy zamieszczono definicję legalną ${ }^{24}$ tego terminu, wedle której żelarzami są „osoby, które w zamian za wykonywanie robocizny na rzecz właścicieli ziemskich mają w użytkowaniu pewne nieruchomości”. Bez wątpienia, co już wykazał Józef Ciągwa, w przypadku spiskich żelarzy chodziło o żelarzy umownych. Świadczą o tym materiały sejmowej komisji pracującej nad ustawą z 1931 r., która ustaliła, że dobra Salamonów i Jugenfeldów powinny zostać objęte węgierską ustawą o uwłaszczeniu żelarzy umownych z $1896 \mathrm{r}^{25}$ Ponadto z ustaleń etnograficznych Marii Hulewiczowej wynika, że wśród polskich żelarzy na Spiszu istniało w latach dwudziestych XX w. bardzo duże zróżnicowanie co do liczby dni pracy na polach pańskich, do których byli zobowiązani ${ }^{26}$. Takie zróżnicowanie nie mogło wynikać z przynależności do grupy żelarzy urbarialnych, których wielkość pańszczyzny była ujednolicona, a musiało wynikać $\mathrm{z}$ indywidualnych ustaleń umownych. Zwróciła już na to uwagę podczas swoich badań etnograficznych Maria Hulewiczowa, wskazując na to, że przechodzące $\mathrm{z}$ ojca na syna obowiązki wobec pana gruntowego musiały mieć swoją genezę w umowie ustnej ${ }^{27}$. Podobnie umowę jako podstawę stosunków pańszczyźnianych na polskim Spiszu wskazywał już wcześniej wybitny znawca historii prawa polskiego Oswald Balzerer ${ }^{28}$.

Jak zatem wyglądała sytuacja faktyczna żelarzy na polskim Spiszu w latach dwudziestych XX w.? Możemy ją poznać dzięki badaniom in situ Marii Hulewiczowej ${ }^{29}$ oraz krótkiej relacji pamiętnikarskiej „ostatniego” żelarza na Spiszu Jana Janosa, napisanej na konkurs ogłoszony w 1959 r. przez Muzeum Tatrzańskie ${ }^{30}$. Maria Hulewiczowa ustaliła, że łączna powierzchnia dóbr Salamonów i Jungenfeldów, obejmu-

\footnotetext{
23 M. Hulewiczowa, Pozostałości ustroju pańszczyźnianego, passim.

24 Definicja legalna to w języku prawnym definicja zamieszczona przez prawodawcę w akcie normatywnym, która jest wiążąca.

25 J. Ciągwa, Zniesienie pańszczyzny, s. 169.

26 M. Hulewiczowa, Pozostałości ustroju pańszczyźnianego, s. 108 n.

27 Tamże.

28 Opinia prof. Oswalda Balzera o żelarstwie na Spiszu, [w: ] M. Hulewiczowa, Pozostałości ustroju pańszczyźnianego, s. $137 \mathrm{n}$.

29 M. Hulewiczowa, Pozostałości ustroju pańszczyźnianego, passim.

30 W. Jostowa, Pamiętnik żelarza, s. 192-196.
} 
jących Niedzicę, Falsztyn i Łapsze Niżne, wynosiła 1793 morgi ziemi rolnej, 396 morgów łąk, 247 morgów pastwisk, 2219 morgów lasów oraz nieużytki. Na obszarze tym zamieszkiwało łącznie 35 żelarzy, posiadających zróżnicowane ilości gruntów w dzierżawie, krowy oraz zabudowania wzniesione na ziemi panów gruntownych. Do tego dochodziło jeszcze 12 służących dworskich niemających ziemi w dzierżawie ani inwentarza, a jedynie posiadających budynki lub ich części pobudowane na gruncie pańskim. Obszar dzierżawionych gruntów przez poszczególnych żelarzy był zróżnicowany i kształtował się od 1 do 7 morgów, przy czym dzierżawy powyżej 4 morgów występowały jedynie w Łapszach Niżnych. Podobne zróżnicowanie dotyczyło posiadanych krów, których poszczególni żelarze mieli od jednej do czterech, przy czym najczęściej dwie lub trzy, i mogli je wypasać na łąkach pańskich. Poza możliwością dzierżawy na swoje potrzeby ziemi rolnej i prawem do wypasu krów żelarze spiscy mieli prawo do pozyskiwania drewna na opał z lasów pańskich w liczbie przeważnie 12 fur rocznie. Wyjątkiem było tu jedynie czterech włościan, którzy mieli prawo do pozyskania mniejszej ilości drewna w wymiarze od 4 do 10 fur. Niestety trudno stwierdzić, z czego to wynikało, z pewnością nie było jednak to skorelowane z wielkością obszaru dzierżawionej ziemi rolnej czy wymiarem pańszczyzny. Być może związane to było z mniejszą liczebnością tych rodzin, ale źródła nie pozwalają na zweryfikowanie tej hipotezy.

Podobnie jak uprawnienia także ciężary na rzecz dworów pańskich były zróżnicowane. Łączny wymiar dni pańszczyzny, do której zobowiązani byli poszczególni żelarze w roku, był uzależniony od dwóch czynników: obszaru dzierżawionej ziemi rolnej oraz wymiaru ustanowionego w zawartej przez danego włościanina z panem umowie. I tak w Niedzicy, w grupie żelarzy, kształtował się on od 30 do 66 dni na morgę ziemi w roku, co dawało razem od 60 do 152 dni pańszczyzny na rok. W Łapszach Niżnych wymiar pańszczyzny był niższy i wynosił od 19 do 23 dni na morgę ziemi, co po uwzględnieniu dzierżawionego obszaru dawało razem od 114 do 180 dni w roku. Tak relatywnie niski wymiar pańszczyzny w przeliczeniu na morgę dzierżawionej ziemi w Łapszach Niżnych wynikał z tego, że jedynie tutaj żelarze dzierżawili znacznie większe obszary - od 6 do 7 morg - niż w pozostałych dwóch wioskach. Z kolei w Falsztynie występowały największe obciążenia w przeliczeniu na dzierżawiony areał i wynosiły od 56 do 90 dni pańszczyzny na morgę. W efekcie, przy stosunkowo małych dzierżawach wynoszących od 1,5 do 4 morg, falsztyńscy żelarze byli najbardziej obciążeni pańszczyzną, która wynosiła łącznie od 114 do 293 dni w roku. Ponadto wszyscy żelarze z Falsztyna byli zobowiązani do wyrębu po 2 metry przestrzenne drzewa $\mathrm{z}$ lasów na rzecz dworów pańskich oraz utrzymywania 
drogi wiodącej z Niedzicy do ich wioski. Oprócz tego większość z nich była zobowiązana do dostarczenia na pański dwór jednej gęsi rocznie. Obowiązek ten dotyczył zapewne jedynie tych żelarzy, którzy posiadali gęsi ${ }^{31}$. Gorsza sytuacja falsztyńskich włościan była spowodowana bez wątpienia niekorzystnymi stosunkami umownymi narzuconymi im przez właścicieli dóbr - Jungenfeldów, którzy cieszyli się w latach dwudziestych XX w. gorszą opinią niż sąsiedni Salamonowie. Dodatkowym czynnikiem sprzyjającym gorszemu położeniu tamtejszych chłopów było to, że Falsztyn leżał zupełnie na uboczu, poza uczęszczanymi drogami, często był wręcz odcięty od świata przez wylewający Dunajec. Inaczej sytuacja wyglądała w dwóch pozostałych wsiach, zwłaszcza w Niedzicy, która z racji ulokowania tam zamku oraz bliskości Czorsztyna miała dużo lepsze kontakty z otoczeniem.

Ciekawym zagadnieniem jest zróżnicowanie świadczeń w przeliczeniu na jednostkę powierzchni dzierżawionego gruntu. Jak już wyżej wskazałem, wynikało to $\mathrm{z}$ umownego charakteru tego obowiązku. Powstaje jednak pytanie, jakimi kryteriami posiłkowali się panowie gruntowi przy określaniu powinności poszczególnych żelarzy. Pomocne okazują się tu wyjaśnienia zarządcy dóbr w Niedzicy, który wskazał na to, że w domostwach, w których nie było dorosłego mężczyzny, określano większy wymiar dni pracy przypadający na morgę dzierżawionej ziemi, ponieważ praca kobiet, młodzieży czy starszych osób z natury była mniej wydajna ${ }^{32}$. Podobnie Maria Hulewiczowa przywołuje świadectwo ówczesnych żelarzy, którzy mieli twierdzić, że cztery dni pracy kobiety były przeliczane na trzy dni pracy pańszczyźnianej, a w przypadku pracy mężczyzny stosunek ten wynosił jeden do jednego ${ }^{33}$. Innymi czynnikami mogącymi wpływać na wymiar pańszczyzny należnej z jednej morgi dzierżawy, jak sugeruje badaczka, mogły być naliczane w przeszłości kary i zaległości przechodzące z roku na rok, które z czasem stawały się niekorzystną dla danej rodziny powinnością utrwaloną w tradycji. Sprzyjał temu analfabetyzm mieszkańców Spiszu i stanowiący konsekwencję tego brak umów sporządzonych na piśmie, które określałyby powinności tamtejszych żelarzy.

Mówiąc o sytuacji prawnej spiskich żelarzy, należy postawić pytanie, czy oprócz pańszczyzny objęci byli oni innymi reliktami poddaństwa, takimi jak poddaństwo

31 Por. M. Hulewiczowa, Pozostałości ustroju pańszczyźnianego, s. 112 n., gdzie tabele z zestawieniami z badań terenowych wymieniające poszczególne nazwiska żelarzy wraz ze wskazaniem ich uprawnień i świadczeń.

32 Archiwum Narodowe w Krakowie. Oddział w Nowym Sączu, Powiatowy Urząd Ziemski w Nowym Sączu 31/111/0.

33 M. Hulewiczowa, Pozostałości ustroju pańszczyźnianego, s. 112. 
osobiste. Dostępne źródła nie potwierdzają tego ani na Spiszu, ani w samych Węgrzech. Żelarze nie byli przywiązani de iure do ziemi, nie podlegali również sądownictwu patrymonialnemu. Ich faktyczne przywiązanie do ziemi wynikało jedynie $\mathrm{z}$ braku wykształcenia, umiejętności konkretnych zawodów i rzeczywistej niemożności opuszczenia osady, w której się urodzili i wychowali.

Jak zatem wyglądał dzień codzienny spiskiego „chłopa pańszczyźnianego” w XX w.? Informacji na ten temat dostarczają etnograficzne relacje Marii Hulewiczowej oraz wspomnienia spisane przez „ostatniego żelarza” na Spiszu Jana Janosa w 1959 r. Żelarze byli ściśle rozliczani z przepracowanych dni na polach pana feudalnego. Ewidencję w latach dwudziestych XX w. prowadzono w formie pisemnych kwitów wydawanych po każdym dniu pracy, w którym w imieniu pana feudalnego administrator zaświadczał, że dana osoba wymieniona z imienia i nazwiska określonego dnia wykonała dniówkę pracy. Kartki te opatrzone były pieczęcią dóbr lub podpisem. Wcześniej przygotowywano również kolorowe drukowane karty opisane w języku węgierskim, na których dana praca wyrażona była określoną kwotą podaną w halerzach. I tak 80 halerzy było wynikiem całego dnia koszenia przez mężczyznę, 60 halerzy efektem całego dnia grabienia przez mężczyznę, a 20 halerzy - całego dnia „małej babskiej pracy” ${ }^{4}$. Na koniec roku obrachunkowego przypadającego na 1 kwietnia, każdy żelarz musiał rozliczyć się z przepracowanych dniówek należnej mu pańszczyzny za pomocą zebranych kwitów, poświadczających przepracowanie poszczególnych dni na pańskim polu. Co ciekawe, istniał obrót tymi kwitami, które stanowiły z jednej strony przedmiot kupna przez żelarzy, którym brakowało przepracowanych dni, a z drugiej stanowiły rodzaj pieniądza zastępczego, którym żelarze mający ich nadmiar płacili w karczmie. Karczmarz z kolei rozliczał się nimi $\mathrm{z}$ dworem, za co otrzymywał określony ekwiwalent pieniężny ${ }^{35}$. Jeżeli jakiś żelarz nie wykonał w roku dni pańszczyzny, do których był zobowiązany, to brakujące dni przechodziły na następny rok, co skutkowało jego większym obciążeniem w kolejnym roku. Innym powodem wzrostu obciążeń w danym roku był system kar stosowanych przez panów gruntowych, którzy za niesubordynację, drobne występki typu kradzieże płodów rolnych z pól pańskich potrafili anulować część kwitów poświadczających pracę obwinionego żelarza. Innym rodzajem kar za niesubordynację, w tym zwłaszcza niestawienie się do pracy, był zwyczaj wyjmowania okien i drzwi przez zarządców z domostw żelarzy, co było niezwykle dolegliwe w miesiącach jesiennych

34 Tamże, s. 116.

35 Tamże. 
i zimowych. Zarządcy pańscy ponadto potrafili konfiskować krowy należące do żelarzy, co w warunkach gospodarki naturalnej skutkowało problemami z wyżywieniem rodzin, zwłaszcza posiadających małe dzieci ${ }^{36}$. Co więcej - w Falsztynie, gdzie ogólnie warunki żelarzy były gorsze, jeszcze w pierwszych latach XX w. Jungenfeldowie stosowali kary cielesne. $\mathrm{W}$ dobrach Salamonów nie mamy już doniesień $\mathrm{z}$ tego okresu o takim traktowaniu chłopów i służby. Wybór dnia 1 kwietnia jako rozliczenia rocznych zobowiązań nie był zapewne przypadkowy i wynikał z rocznej organizacji pracy w tradycyjnej gospodarce rolnej, gdzie początek wiosny był okresem początku cyklu produkcyjnego.

Stosunki żelarzy z pańskimi dworami uległy zaostrzeniu w drugiej połowie lat dwudziestych XX w. z powodu podnoszenia inicjatyw zniesienia pańszczyzny na polskim Spiszu i uwłaszczenia żelarzy. Rodzina Salamonów w swoich pismach kierowanych wówczas do Urzędu Ziemskiego w Krakowie oraz Ministerstwa Reform Rolnych skarżyła się, że ludność zamieszkująca ich dobra poddawana była agitacji komunistycznych działaczy ludowych ${ }^{37}$. Baron Salamon stwierdzał w jednym z tych pism, że „wskutek przewłoki w rozwiązaniu stosunku spornego, ten ostatni między dworem a włościanami jest bardzo naprężony i niebezpieczny" ${ }^{38}$. Z kolei żelarze z Falsztyna skarżyli się, że pastwiska, których używali, zarządca dóbr w Falsztynie „dał zaorać, a nowe pastwiska, które nam komisja przyznała, właściciel wynajął obcym ludziom do wypasania owiec, twierdząc, że jeszcze żelarze nie mają oddane przez komisję, by mogli paść bydło ${ }^{39}$.

Pierwsza wojna światowa i przeobrażenia społeczno-gospodarcze jej towarzyszące odbiły się również na sytuacji włościan w górskich regionach Spiszu. Udział tamtejszych mężczyzn w wojnie, skutkujący zetknięciem się z ludnością z innych stron Austro-Węgier, spowodował przemiany świadomościowe u tamtejszej ludności. Zetknąwszy się z ludnością z innych stron kraju, żelarze zrozumieli, że to, co znane im było od urodzenia, jest jedynie przeżytkiem dawnych czasów niespotykanym w innych stronach cesarstwa. Wojna spowodowała też migracje ludności, co

\footnotetext{
36 Opis trudów pracy żelarzy przekazała krótka relacja wspomnieniowa Jana Jarosa z Niedzicy, zob. W. Jostowa, Pamiętnik żelarza, s. 194 n.

37 M. Hulewiczowa, Pozostałości ustroju pańszczyźnianego, s. 120.

38 Tamże.

39 Archiwum Narodowe w Krakowie, sygn. 29/3521/0/25 Powiatowy Urząd Ziemski w Nowym Targu: Likwidacja stosunków czynszowniczo-pańszczyźnianych na Spiszu i Orawie (wykaz żelarzy na Zamku Niedzica, orzeczenia, prośby poddanych o zwolnienie ze świadczenia robót pańszczyźnianych w majątku Falsztyn).
} 
dodatkowo sprzyjało kontaktom z osobami żyjącymi w innych realiach społecznych. Kolejnym katalizatorem przemian stały się wydarzenia rozgrywające się po roku 1918. Organizowane przez stronę polską i czeską po pierwszej wojnie światowej plebiscyty powodowały wzrost świadomości narodowej i społecznej na Spiszu ${ }^{40}$. Podczas tych akcji obie strony, starając się przekonać mieszkańców, obiecywały różne korzystne dla nich rozstrzygnięcia. Część z nich dotyczyła rzecz jasna położenia prawnego spiskich żelarzy. Na konkretne działania prawne przyszło jednak spiskich włościanom poczekać kilka kolejnych lat.

Jak wykazał Józef Ciągwa, pierwsze wzmianki na temat zniesienia pańszczyzny na Spiszu zawierały źródła z lat dwudziestych, powstałe przy okazji przygotowań do likwidacji stosunków żelarskich ${ }^{41}$. Już wtedy zastanawiano się, w jaki sposób rozwiązać ten problem i przeważyły argumenty za tym, że należy rozwiązać zniesienie tego reliktu ustroju feudalnego w sposób kompleksowy na poziomie regulacji ustawowej $^{42}$. $\mathrm{Z}$ innego dokumentu powstałego w tym czasie wynika, że sugerowano zwrócenie się o opracowanie ekspertyzy prawnej do wybitnego polskiego historyka prawa profesora Oswalda Balzera oraz do znawcy stosunków społecznych na Spiszu ówczesnego dyrektora liceum w Lewoczy doktora Adorjána Divékyego ${ }^{43}$. Ostatecznie jedynie profesor Oswald Balzer sporządził opinię w tym zakresie datowaną na 16 I $1921 \mathrm{r} \cdot{ }^{44}$ Lwowski profesor prawa postulował rozwiązanie problemu żelarstwa na polskim Spiszu przez wypłatę odszkodowania dotychczasowym właścicielom ziemskim, na wzór wcześniejszych regulacji węgierskich. Postulowane rozwiązanie nie zostało jednak wprowadzone w życie, a na ostateczne uregulowanie tej kwestii przyszło poczekać kolejne 10 lat.

W tym czasie na skutek skarg samych zainteresowanych, raz po raz dochodziło do interwencji na szczeblu politycznym. I tak 18 XII 1924 r. pierwszą interpelację w polskim Sejmie w tej sprawie złożył poseł PSL Józef Bednarczuk ${ }^{45}$. Ta interwencja nie przyniosła jednak żadnej intensyfikacji działań w tej sprawie. Trudno stwierdzić,

40 Archiwum Narodowe w Krakowie. Ekspozytura w Spytkowicach, Teczka materiałów plebiscytowych, nr 11.

41 Archiwum Akt Nowych w Warszawie, zespół MSW, nr 678, k. 638-674. Por. J. Ciągwa, Zniesienie pańszczyzny, s. 172.

42 Archiwum Akt Nowych w Warszawie, zespół MS, nr 678, k. 641.

43 Tamże, k. 638 n.

44 Opinia prof. Oswalda Balzera, s. 137-139.

45 Sprawozdanie stenograficzne ze 172 posiedzenia I Sejmu RP z dnia 18 grudnia 1924 r., k. CLXXII/47. 
z czego wynikała ta opieszałość władz. Zachowane źródła archiwalne milczą na ten temat. Bez wątpienia zasadniczą przyczyną był w tym wypadku marginalny problem spiskich żelarzy na tle problemów, z którymi przyszło zmierzyć się odrodzonemu państwu polskiemu po $1918 \mathrm{r}$. Wszak spiskich żelarzy było jedynie kilkudziesięciu i ich położenie miało bardziej wymiar symboliczny niż realny w skali problemów ogólnokrajowych. Inną przyczyną mogła być ta, że zgodnie z art. 1 ustawy z $26 \mathrm{X}$ 1921 r. w przedmiocie przepisów prawnych obowiązujących na terenie Spiszu i Orawy, które weszły w skład II Rzeczypospolitej, obowiązywała ustawa węgierska nr XXV/1896, która uwłaszczała żelarzy umownych z obowiązkiem spłaty z ich stro$n y^{46}$.

Problem spiskich żelarzy powrócił na polską scenę polityczną dopiero w początku lat trzydziestych. Pierwszy z wnioskiem o rozwiązanie tego kompromitującego państwo polskie problemu zwrócił się z ławy sejmowej poseł BBWR Feliks Gwiżdż 16 XII 1930 r. Od tej chwili sprawa nabrała nowej dynamiki. Już w lutym następnego roku za sprawą Feliksa Gwiżdża Komisja Reform Rolnych zarekomendowała projekt ustawy o likwidacji stosunków żelarskich na Spiszu. Projekt ten zyskał poparcie izby niższej, a następnie po kilku drobnych poprawkach Senatu został przyjęty przez Sejm 20 III 1931 r. ${ }^{47} \mathrm{~W}$ ten sposób, na mocy ustawy o likwidacji stosunków żelarskich na Spiszu, która po podpisaniu przez Prezydenta RP weszła w życie 23 IV 1931 r., smutny relikt epoki feudalnej de iure przestał istnieć.

Jakie zatem rozstrzygnięcia wniosła marcowa ustawa? Zgodnie $\mathrm{z}$ art. 1 ustawa pozwoliła żelarzom nabyć na własność za odpowiednią cenę wykupu użytkowane przez nich nieruchomości na terenie polskiego Spiszu. Dodatkowo, na mocy art. 3 żelarze mieli prawo do nabycia pastwisk, na których do tej pory mieli prawo wypasania bydła. Ustawa ta ustaliła ceny wykupu tychże ziem na kwotę 216 zł za hektar użytków gruntu ornego w pierwszej klasie (art. 2 ust. 1), odpowiednio korygowanej na podstawie rozporządzenia ministra reform rolnych ${ }^{48} \mathrm{w}$ odniesieniu do klas niższych ziemi (art. 2 ust. 2). Zgodnie z art. 4 tej ustawy z chwilą wykupu nieruchomości przez żelarzy miały ustać wszelkie dotychczasowe ich zobowiązania pańszczyźniane

46 Ustawa z dnia 26 października 1921 r. w przedmiocie przepisów prawnych, obowiązujących na obszarze Spisza i Orawy, należącym do Rzeczpospolitej Polskiej, Dz. U. Nr 89 z 1921 r., poz. 657.

47 Ustawa z dnia 20 marca 1931 r. o likwidacji stosunków żelarskich na Spiszu, Dz.U. Nr 37 z 1931 r., poz. 288.

48 Rozporządzenie Ministra Reform Rolnych do ustawy z dnia 28 grudnia 1925 r. o wykonaniu reformy rolnej Dz.U. Nr 1 z 1926 r., poz. 1. 
względem panów gruntowych, a w myśl art. 5 zaległe zobowiązania żelarzy miały zostać umorzone. Wdrażanie ustawy z 20 III 1931 r. miały przeprowadzać komisje powołane do wykupu nieruchomości żelarskich na Spiszu, a w drugiej instancji komisja ziemska w Krakowie (art. 6). Skarb Państwa wziął przy tym na siebie koszty postępowań administracyjnych i sądowych z tym związanych (art. 16), a sami żelarze mogli liczyć na preferencyjne kredyty na wykup użytkowanych przez siebie ziem z funduszu Ministerstwa Reform Rolnych (art. 17). Istotnym mankamentem tej ustawy było to, że regulowała ona jedynie kwestię wykupu ziemi ornej i pastwisk użytkowanych przez żelarzy oraz budynków mieszkalnych i gospodarczych przez nich wzniesionych na ziemi panów gruntowych, pomijając kwestię lasów, które nadal w całości należały do majątków dworskich. Z chwilą uwłaszczenia żelarze tracili w ten sposób możliwość pozyskiwania drewna opałowego i drewna na budowę z lasów pańskich i odtąd musieli kupować drewno na wolnym rynku.

Z chwilą wejścia w życie ustawy ostatni spiscy żelarze zaprzestali wykonywania pańszczyźnianych obowiązków. Wnet swe prace zaczęła powołana 20 V 1931 r. przez ministra reform rolnych komisja do spraw wykupu nieruchomości żelarskich na Spi$\mathrm{szu}^{49}$. Ciało to podjęło działalność już w lipcu tego roku orzeczeniem o wszczęciu postępowania w sprawie wykupu nieruchomości żelarskich ${ }^{50}$. Prace komisji trwały na pewno do wiosny 1934 r., o czym świadczy wydane 29 V 1934 r. orzeczenie kończące spory co do wykupu nieruchomości żelarskich w Niedzicy ${ }^{51}$. W ten sposób $\mathrm{w}$ połowie lat trzydziestych $\mathrm{XX}$ w. te ostatnie relikty ustroju feudalnego w postaci pańszczyzny w Europie przestały istnieć.

Nadesłany: 15 I 2021

Nadesłany po poprawkach recenzyjnych: 27 I 2021

Zaakceptowany: 28 I 2021

Dr hab. prof. UJK Wojciech Baran-Kozłowski

Instytut Nauk Prawnych Uniwersytetu Jana Kochanowskiego w Kielcach

ul. Uniwersytecka 15, 25-406 Kielce

barankozlowski@gmail.com

\footnotetext{
49 J. Ciągwa, Zniesienie pańszczyzny, s. 176.

50 Tamże.

51 Archiwum Narodowe w Krakowie. Ekspozytura w Spytkowicach, sygn. R IX, 2/N/30, s. 46, cyt. za tamże, s. 176, przyp. 52.
} 


\section{Resume}

The last serfs in contemporary Europe: relicts of serfdom in Spiš and abolition thereof in the 1930s

A part of Spiš, formerly within the Kingdom of Hungary, was incorporated into the Second Polish Republic on 28 July 1920. In this region there were three villages (Niedzica, Falsztyn and Niżne Łapsze) owned by two related families: the Salamons and the Jungenfelds. Back then, the villages were relics of feudal relations in the form of obligatory provision of serfdom for the landlords. The involved peasants were referred to as "żelarze". Their origin goes back to the late Middle Ages and their population had been quite numerous throughout Hungary. In the areas of the Kingdom of Hungary other than Spiš, the serfdom of the castellars was partially abolished in 1848 (urbarial), and entirely in 1896 (conventionally). However, in the Spiš enclave on the border of Slovakia and Poland, these relations lasted until 20 March 1931 when the status quo was changed by a legal act. During the next three years, the "żelarze" were granted ownership by purchasing the land they cultivated and the buildings they used at statutory prices.

Ttumaczenie: Ewa Dratwa 